\title{
Determinants of Conservation Among the Rural Poor: A Charitable Contributions Experiment
}

\author{
Deanna Karapetyan \\ Department of Economics \\ University of San Francisco \\ 2130 Fulton St. \\ San Francisco, CA 94117
}

Email: deannakarapetyan@yahoo.com

\author{
Giovanna d'Adda \\ Department of Economics \\ University of Birmingham \\ JG Smith Building \\ B15 5TT, UK
}

Email: g.dadda@bham.ac.uk

December 18, 2013

\begin{abstract}
This paper examines how conservation decisions are affected by environmental degradation. Donations to an environmental NGO and participation in actual conservation activities capture individual preferences for environmental conservation. Environmental degradation is measured both through survey-based data on experiences of deforestation and environmental shocks, and through indices of deforestation constructed with GIS data. The results show that being exposed to environmental degradation is correlated both with higher donations and conservation behavior. The relationship between conservation choices and individual social preferences is also explored. Experimental measures of individual altruism and inequality aversion, and survey measures of trust, time preferences and civic engagement are correlated with donations and real world conservation decisions respectively. These findings show the role of environmental awareness in fostering environmental conservation even in very poor settings. They also highlight the potential of experiments, which closely mirror real world decisions, to generate conclusions generalizable to individual behavior outside the laboratory.
\end{abstract}

JEL Classifications: C71, C93, 012, 020, Q20 


\section{Introduction}

Promoting sustainable use of natural resources is one of the main challenges facing policy makers in developed and developing countries alike (Millennium Ecosystem Assessment, 2005; TEEB, 2010). While developed countries adopt laws and sanctions to regulate the use of common property resources (henceforth CPR), developing countries often lack the institutional capacity to design and enforce the complex measures to address environmental problems (Dietz et al., 2003). Sustainable management of natural resources in poor countries often relies on informal systems managed by users themselves (Wade, 1987). Given the role of collective action in promoting sustainable resource use in these settings, understanding what influences environmental valuation and generates support for locally owned solutions is a priority both for policy makers and researchers (Agrawal, 2001; Gibson et al., 2005).

Research on these issues can have a large impact on development and poverty reduction. The negative consequences of environmental degradation are likely to be more severely felt in poor countries (Stern, 2006; Mendelsohn et al., 2006). Heavier reliance on fresh water, pastures, and forests, for example, results in greater vulnerability to environmental shocks, such as flooding, droughts and soil erosion (Morton, 2007). Research shows how environmental degradation in general, and deforestation in particular, affect those who rely on natural resources for their livelihoods (Bucknall et al., 2000). Such negative effects are stronger among more vulnerable family members, such as children (Nankhuni \& Findeis, 2004). Long firewood collection time may also expose the female population of a developing country to danger in conflict zones (Bizzarri, 2009).

This paper examines factors associated with individuals' choices to contribute to environmental conservation in rural Sierra Leone. We focus on two potential correlates of conservation behavior: social preferences and exposure to environmental degradation. First, through an artefactual field experiment (Harrison \& List, 2004), which closely mirrors actual conservation decisions faced by participants in their daily lives, and survey measures of actual conservation behavior, we analyze the relationship between environmental conservation and other types of social preferences, measured using experimental and survey data. Second, we examine the 
correlation between conservation choices and indices of environmental degradation, both collected through survey questions and constructed from GIS deforestation data.

Conservation behavior is defined here as the preservation and management of the environment and common natural resources. Consequently, our dependent variables donations to a conservation NGO, participation in town cleaning and maintenance of the village's water sources - capture actual conservation behavior. Participants to the experiment decide how much to donate to a local NGO conducting environmental education and conservation campaigns in the country. We complement this experimental measure with survey data on two real-world conservation activities: town cleaning and maintenance of public water sources. These activities are common practices among sample villages, where community members get together to clean common spaces and protect them from contamination by animals. The three dependent variables used in this study differ not only in the method used to collect them, but also in their relation to environmental conservation more specifically, rather than to social preferences and civic engagement more broadly.

The paper is articulated as follows. First, we discuss the relevant literature on CPR management and review factors associated with more effective management systems (Section 2). We then give an overview of the study design, data, and empirical strategy (Section 3). We present and discuss the empirical results in Section 4 and 5, respectively. Section 6 concludes.

\section{The common pool resource problem}

CPR are characterized by non-excludability and rivalry in consumption. The difficulty of excluding individuals from use, combined with the fact that consumption by one individual reduces the amount of resources available to others, imply that CPR users face a typical cooperation dilemma. Each individual depends on the resource for her livelihood and has the incentive to maximize her own benefit by increasing extraction. However, if everyone follows the same rationale, the resource will be depleted and will not generate benefits for anyone in the long term. In an influential article, Hardin (1968) claims that the behavior of rational, self-interested individuals is bound to result in overexploitation of CPR. This conclusion is consistent with game theoretical 
predictions and is confirmed by numerous examples of overharvesting of renewable natural resources, such as fisheries, forests and groundwater.

A large literature on CPR management questions this vision, by offering evidence of effective cooperation to solve commons problems. Field experiments show that collective action is most effective when communities are able to self-organize, and design and enforce their own rules (Wade, 1986; Ostrom et al., 1999; Baland and Platteau, 1996). Among factors influencing the effectiveness of CPR management is environmental degradation. The relationship between conservation and degradation is complex: while overexploitation of natural resources leads to environmental degradation, a certain degree of resource degradation is necessary to trigger collective action for conservation. Among the different types of resource attributes that contribute to self-organized forest management, Elinor Ostrom (1999) underscores the importance of feasible improvement. Feasible improvement refers to a resource that is "not at a point of deterioration such that it is useless to organize or so underutilized that little advantage results from organizing" (Ostrom, 1999). Empirical evidence shows that cooperation levels are low when the CPR is either abundant or extremely degraded, but high when the level of degradation is at a moderate level (Bardhan, 2000).

Dependence on the CPR for a major portion of one's livelihood is also claimed by Ostrom (1999) to be a factor leading to greater interest in conservation of the resource. Empirical evidence from Malawi shows that, where forests serve as safety nets for people, individuals have higher rates of participation in CPR management (Jumbe \& Angelson, 2007).

Social preferences, such as altruism, inequality aversion, trust, time preferences and civic engagement, are likely to affect CPR management since they shape individuals' response to the trade-offs between individual and social benefits from environmental conservation. Their role is bound to be particularly relevant in developing country settings, where social norms often substitute for formal institutions lacking regulatory and enforcement capacity (Narayan, 1999; Khan, 2006). The empirical evidence on the relationship between social preferences and environmental conservation widely supports this view (Goeree, Holt \& Laury, 2002). 
In particular, an individual's level of altruism is likely to be positively correlated with her contribution to a local public good because an altruistic person's utility is a positive function of others' consumption. This view is in contrast with the traditional notion of self-interested individuals, whose utility depends solely on one's own consumption (Becker, 1976; Reece, 1979; Collard, 1978).

Preferences for fairness are also likely to foster sustainable management of CPR through their influence on people's willingness to contribute to public goods and to punish over-exploitation by others. Direct evidence on the link between inequality aversion and public good contribution is scarce, but research in psychology (Lerner, 1980; Bégue \& Hafer, 2005) and economics (Andreoni, Harbaugh, \& Vesterlund, 2003) shows that people express their preferences for fairness by punishing inequality in resource allocation.

The literature on social capital and collective action identifies trust as a necessary condition for cooperation within a society (Ostrom, 1998; Cramb, 2005; Pretty, 2003; Pretty \& Smith, 2004). Experimental studies show the presence of a positive correlation between trust towards strangers, contributions to public goods (Gächter, Herrmann, \& Thöni, 2004) and other social preferences, such as fairness (Walker \& Ostrom, 2007). Field evidence supports the results from laboratory experiments: combining data from a trust game with information on investments in soil and water conservation, Bouma et al. (2008) find a positive and significant correlation between the amount sent in the trust game and participation in CPR management.

Investing in conservation involves a trade-off between short term costs and uncertain returns in the future. The degree to which individuals discount the future is therefore likely to affect the perceived benefits from contributing to natural resource conservation. The evidence on whether the poor discount the future more heavily, and on how discount rates translate into conservation activities, is mixed. In a three country study, Holden et al. (1998) find that poverty is associated with higher discount rates and lower conservation efforts. On the contrary, research based on food consumption and asset holding during famines shows that the poor reduce caloric intake during periods of food scarcity in order to avoid selling off productive assets (Moseley, 2001), suggesting the presence of a relatively low discount rate. Regardless 
of the evidence on the relationship between poverty and time preferences, theory predicts a negative correlation between an individual's discount rate and her environmental conservation efforts.

Natural resources are a local public good, and their management requires collective action on the part of the community. Evidence from high-income countries shows that participation in city council and school meetings is associated with a higher probability of engaging in collective action for conservation (Wakefield, Elliott, \& Cole, 2007). Membership in community associations is found to be associated with higher contribution to conservation projects in two artefactual field experiments in Latin America (d'Adda, 2011a; d'Adda, 2011b).

While the evidence presented so far suggests a close relationship between social preferences and conservation behavior, Voors et al. (2011), in a paper representing the closest parallel to the research conducted here, show the complexity of such a relationship. Participants to their study play two public good games, a framed and an unframed one. Experimental choices are compared to survey data on illegal exploitation of forest resources and support for conservation activities. The main findings of the study are that behavior in the two experimental games is only weakly correlated, and that only positive contributions in the framed experiment are associated with higher conservation efforts outside of the experiment.

More generally, the literature on environmental valuation presents many examples of the weak correlation between measures of environmental preferences and conservation behavior. Evidence from developed countries shows how environmental concerns influence conservation behavior only when it entails low costs and inconvenience for individuals (Diekmann and Preisendörfer 2003), and that there is a strong income elasticity of conservation behavior (Poortinga et al. 2004). Data from developing countries confirms these patterns, as revealed preference estimates of environmental valuations are lower than stated preferences estimates, and demand for a high quality environment is highly income elastic (Kremer et al., 2011).

\section{Research Design and Empirical Strategy}


In this section, we describe the area where the study took place (Section 3.1), and the main sources of data for the study (Section 3.2). We then focus on the experimental design (Section 3.3), and lastly, present the empirical strategy and the main variables used in the analysis (Section 3.4).

\subsection{Research area}

The study took place in Sierra Leone. The country has one of the lowest HDI rankings in the world - 158 th out of 169 countries (Human Development Report, 2010) and experienced a devastating civil war between 1991 and 2002. Coupled with its high levels of poverty, the fact that Sierra Leone has suffered severe environmental degradation over the past thirty years makes it a suitable setting for our study. Figure 1 shows that resource extraction in the country over the past decades has been steadily approaching the capacity of natural resources to regenerate themselves. This trend is likely to threaten the livelihood of $69 \%$ of the population who live in rural areas and directly depend on natural resources for their survival. ${ }^{1}$

\section{[Insert Figure 1 here]}

Figure 2 shows the location of the study area is within the district of Bombali, where high rates of deforestation have been experienced, similar to the rest of the country as a whole. The fact that people rely on natural resources for their livelihoods and are negatively affected by environmental problems emerges also by looking at our survey data: $90 \%$ of the participants in our study extract products from the forest, $59 \%$ mention bush fires as an environmental problem in their village, and 69\% report an increase in the price of firewood.

[Insert Figure 2]

The experiment took place in 21 villages within Bombali district, with 560 individuals between the ages of 18 and 84 participating in the study. The experiment

\footnotetext{
${ }^{1}$ World Bank data, 2009. Link: data.worldbank.org/country/sierra-leone.
} 
was part of a larger research project, investigating the relationship between conflict exposure and social preferences, and the transmission of preferences across generations. Consistent with these goals, the villages in our sample were selected on the basis of an index of exposure to civil war violence, and the experiment was conducted in primary schools with pupils and their parents. Only adult participants completed the task analyzed in the present paper. Therefore, in what follows, we will solely discuss the adult component of the study. ${ }^{2}$

Table 1 summarizes characteristics of study participants. Many children in our sample were living with grandparents after their parents died due to the war, or moved to the city for work: this explains the relatively high average age of participants for a developing country. Only 26 percent of participants had some schooling, 75 percent of them worked in agriculture, and their average weekly income per capita was about 49,000 Leones (less than 10 USD). The percentage of households that fled from their villages during the civil war is 87.

[Insert Table 1 here]

\subsection{Data}

The dataset used in the empirical analysis combines experimental, survey, and GIS data. The experimental design is described in detail in Section 3.3 below, while this sub-section focuses on the data collected through participants' interviews and spatial analysis.

The survey collected information on demographic and socioeconomic characteristics, preferences, exposure to environmental degradation, and participation in environmental conservation activities and civic engagement. In what follows, we briefly describe the contents of the survey. ${ }^{3}$

Socioeconomic characteristics include age, gender, marital status, education level, religion, ethnicity, occupation, household size, number of years living in the village, household per capita expenditure, and a series of questions on conflict exposure.

\footnotetext{
${ }^{2}$ For a detailed account of the broader research, within which the present study was set, of its design and results, see Bauer, Cassar, Chytilova and Henrich (2011).

${ }^{3}$ A complete overview of the survey questions is offered in Appendix B.
} 
A set of questions concerned trust and time preferences. Our measure of trust is derived from a series of standard questions, taken from the World Value Survey. Respondents are asked to state their trust towards different groups of people: family members, friends, neighbors, and people in general. Trust variables range from one to three, where three represents the highest level of trust. A standard time preference question, facing respondents with six hypothetical situations where they had to choose between receiving a certain amount of money in the present or a larger sum in a month, is used to compute participants' discount rate. The amount offered in the future ranged from 100,000 Leones (25 USD), equal to the amount offered in the present, up to 300,000 Leones.

Exposure to environmental degradation is measured through questions on income lost due to factors related to the quality of the environment, either in the form of increased time to collect firewood or loss of harvest due to shocks. We also collected a proxy of dependence on natural resources, given by the number of products that individuals extract from the forest, such as firewood, timber, fruits, honey, etc.

Respondents' conservation behavior was measured through two questions asking about participation in conservation activities: (1) subjects were asked whether they had participated in the maintenance of the main water source used by their household the last time it was performed, and (2) in cleaning the town over the previous year. These activities capture preferences towards conservation because environmental degradation represents a threat to the quality of water and to the village environment.

Finally, a series of questions related to participation in community meetings, local and general elections, and membership in community associations. These activities all signal an individual's involvement in public life.

GIS data are used to derive measures of deforestation at the village level. Village level satellite observations of changes in forest cover between 2006 and 2010 were constructed based on NASA Landsat images and village GIS coordinates, obtained from the Community Forest Conservation and Agricultural Development Association of Sierra Leone. ${ }^{4}$

\footnotetext{
${ }^{4}$ The village level deforestation measure was constructed in ArcGIS from cloud free NASA Landsat images of Sierra Leone for the years 2006 and 2010. These images had to be corrected for atmospheric scattering and absorption of
} 
Other village level characteristics were collected through a survey conducted with the village chief. This survey gathered information on population, distance to the nearest town; presence of health centers and daily markets, conflict intensity - proxied by the number of houses burnt in the village during the war- and indicators of living conditions in the village.

\subsection{Experimental design}

Participants to the experiment completed a series of tasks, designed to capture different dimensions of social preferences. Among others, participants played dictator and ultimatum games. ${ }^{5}$ In both games, subjects could send between 0 and 4 tokens to an anonymous partner, in intervals of 1 token. Each token was worth 1,000 Leones (about 0.25 USD). In the ultimatum game, subjects made decisions both as senders and as receivers. Receivers in the ultimatum game used the strategy method: they had to decide, for each possible amount given by the sender, whether to accept the allocation or not. When a receiver didn't accept the sender's proposed allocation of tokens, neither party received anything. The order of tasks was randomized across sessions. The amount sent by subjects in these two games provide the experimental measures of social preferences that will be used in the empirical analysis. Details on variables' definition are given in the next sub-section.

After completing all the tasks, participants were asked whether they would like to donate a small part of their earnings to an environmental nonprofit organization called the Conservation Society of Sierra Leone (CSSL). CSSL is based in Freetown, and its main objective is 'to promote the wise use and management of Sierra Leone's natural resources through education, advocacy, research and site action' (CSSL). Their

light, which is based on the methodology that Chavez (1996) streamlined. After these corrections were made, the soil adjusted vegetation index (SAVI) was calculated:

$\mathrm{SAVI}=(\mathrm{N}-\mathrm{R}) /(\mathrm{N}+\mathrm{R}+\mathrm{L})(1+\mathrm{L})$

where $\mathrm{N}$ is the near-infrared band (Landsat TM Band 4); $\mathrm{R}$ is the red band (Landsat TM Band 3); and L is a correction factor between 0 and 1 (in this study, a mid-range value of $\mathrm{L}=0.5$ was used). The difference between the SAVI in 2006 and 2010 was taken, and village GPS coordinates for 19 out of the 21 villages were manually added in ArcGIS. A 2mile zone around each village was constructed, and the average level of vegetation cover decrease within each zone was used as the deforestation variable for that village.

${ }^{5}$ Beside the dictator and ultimatum games, subjects played four binary-choice dictator games, taken from Bauer et al. (2011) and inspired by Fehr et al. (2008). Since data from these games are not used in the empirical analysis, we omit a detailed description, but refer the interested reader to Bauer et al. (2011). 
programs range from sea turtle and forest conservation to environmental education and sensitization campaigns. Participants were given brief information about CSSL before being asked for a donation.

Donations went to support non-rival and non-excludable conservation efforts. Under this respect, the experiment is similar to most public good games. However, our donation experiment differs from a public good game in a crucial dimension: the return from the investment in the public good is not exogenously given, but is subject to the same uncertainty that characterizes real world investments in common natural resources. This feature of our study, while generating a loss of experimental control, makes the experimental decision more generalizable and directly comparable to participants' real world conservation choices.

Participants could decide to donate $0,300,800$ or 1000 Leones from their winnings to CSSL. 6 The experimenter emphasized that the donation would be subtracted from their winnings from the day, that no other tasks would follow, and that contributions were completely voluntary. Participants didn't know how much they earned through the tasks at the time of choosing their donation, since they received their winnings only at the end of the experimental session, but had a sense of the magnitude of their final earnings relative to the possible donation amounts. Each participant was given what she earned for participation, plus what she earned for her choice in a randomly chosen task, minus her donation amount to CSSL. The participation fee was equal to 5,000 Leones (about 1.25 USD). Although each task had different earnings potential, earnings from the games ranged between 0 and 16,000 Leones (about 4 USD).

In order to test whether donation amounts depend on the perceived beneficiary of the service, we introduced an experimental treatment. CSSL's activities were said to be beneficial for 'people in the whole country' in the out-group treatment, and for 'people in this region' in the in-group treatment. The allocation of treatment across sessions was random. We conducted two sessions in each village, in order to have observations for both treatments from each village.

\subsection{Analysis}

${ }^{6}$ The price of a cup of rice, staple food in Sierra Leone, is 500 Leones. 
In order to analyze the factors correlated with conservation behavior within the experiment, we run the following regression:

$Y_{i j}=\alpha+\beta Z_{i j}+\gamma X_{i j}+\delta V_{j}+\varepsilon_{i j}$

where the dependent variable $Y_{i j}$ is donation amount, participation in water maintenance or in town cleaning. In our main specifications, we use ordered probit regressions for donation, and probit regressions for participation in conservation activities. In addition, we consider a dependent variable equal to 1 when an individual displays strong preferences for conservation along all three dimensions considered here; i.e. when an above-average amount is donated and participation has occurred in both conservation activities. $Z_{i j}$ is a vector of six variables, capturing the six correlates of conservation we focus on. $X_{i j}$ is a vector of individual and household level controls. $V_{j}$ are village fixed-effects or village level characteristics. $\boldsymbol{\beta}$ and $\boldsymbol{\gamma}$ are coefficient vectors. The observations are clustered at the village level. ${ }^{7}$ In order to address concerns related to the use of fixed-effects in non-linear regression models, in what follows, we also present results of OLS regressions for each outcome variable.

Our main outcome variables are different proxies of environmental valuation and conservation behavior. First, we use the amount donated to CSSL as our experimental measure of environmental valuation. The two conservation activities, considered here as outcome variables, capture subjects' concern with the quality of the village's water supply and common spaces.

In the empirical analysis, we focus on six factors potentially correlated with conservation behavior: one of two versions of an index capturing exposure to environmental degradation and dependence on natural resources (henceforth exposure-dependence index), altruism, inequality aversion, trust, time preferences and civic engagement. In what follows, we describe each variable in turn.

\footnotetext{
${ }^{7}$ Assuming that village fixed-effects control for unobservable differences across villages and that observations from the same village are uncorrelated if individuals did not participate to the same experimental session, an alternative specification clusters the data at the session level. This specification, bringing the number of clusters from 21 to 42 , also solves the issue of having too few clusters (Cameron and Miller, 2010). All the findings reported in this section are robust to the level of clustering chosen.
} 
We adopt a subjective or an objective version of the exposure-dependence index in different specifications. The subjective version of the index proxies exposure to environmental degradation with a measure of experienced environmental degradation. This variable is equal to one if the respondent experienced increased firewood collection time or lost income due to an environmental shock over the two, or three, years prior to the survey, respectively. In order to combine exposure to degradation with dependence on natural resources, and thus test Elinor Ostrom's claim that the combination of these two factors fosters conservation behavior, the environmental degradation variable is interacted with the number of products that individuals extract from the forest.

Using subjective perceptions as a proxy of environmental degradation makes the establishment of any causal link between environmental degradation and donation questionable. Unobserved individual characteristics may determine both individuals' awareness of environmental degradation and their willingness to contribute to conservation activities. For instance, it is likely that, for a given level of environmental quality, characteristics such as education, income and exposure to conservation campaigns may influence both the perception of environmental degradation and the willingness to support conservation activities. In order to address the issues associated with the use of experienced environmental degradation, we complement our subjective proxy of environmental degradation with more objective measures of deforestation.

In the objective version of the exposure-dependence index, experienced environmental degradation is replaced with actual deforestation rates over the 5 years prior to the study. This approach guarantees that the environmental degradation variable used to construct the objective version of the index reflects more closely the effect of loss of forest cover on respondents' exposure to environmental degradation. The use of actual deforestation, although addressing the issues related to the adoption of experienced degradation, also involves important shortcomings. While mining and illegal logging by foreign companies are major causes of deforestation in other regions of Sierra Leone, deforestation in this study area is primarily the result of firewood collection and slash-and-burn agriculture by local communities. It is possible that 
present conservation choices are the product of common resources' exploitation in the past, and unobservable individual preferences or characteristics lie behind both past deforestation and donation choices within the experiment. Therefore, the actual deforestation measure, while capturing individuals' exposure to degradation, also reflects past preferences for conservation of village members. We will show in Section 4 that this latter effect appears to dominate.

Participants' altruism and inequality aversion measures are derived from experimental data. We use the number of tokens sent in the dictator game as an ordered categorical proxy of altruism (Camerer, 2003). Inequality aversion is a variable equal to one if a participant equally split her endowment both in the ultimatum and in the dictator games. ${ }^{8}$

Individual trust is captured by a trust index, defined as the ratio of personalized to generalized trust. The index is constructed by dividing the average trust towards family, friends and neighbors by the level of trust towards people in general, and can be interpreted as a measure of social capital within the village. Time preferences are summarized by the discount rate, constructed using the set of survey questions on trade-offs between present and future consumption.

Subjects' participation in community meetings, local and general elections and membership in community associations is used to derive an index of civic engagement. The index is constructed as follows: for each dimension of civic engagement, individual participation is divided by the average level of participation at the village level; the different dimensions are then summed to form a unique index.

Regressions also control for individual and household characteristics, such as age, gender, marital status, education level, religion, ethnicity, occupation, household size,

\footnotetext{
${ }^{8}$ Alternative measures of inequality aversions could be used. Combining choices in the four binary allocation games, Fehr et al (2008) construct an index of inequality aversion. We do not adopt this approach because only 9.6 percent of subjects (54 observations) can be defined as inequality averse based on their choices in the binary allocation games. A less demanding version of the inequality aversion proxy would require participants to split their tokens equally either in the ultimatum or in the dictator game. We prefer the stronger definition of egalitarianism used here because it identifies participants who consistently chose equal splits in the two tasks. However, the results reported in Section 4 are robust to the inequality aversion index used.
} 
number of years living in the village, household per capita expenditure and an index of conflict exposure. ${ }^{9}$

Table 2 shows summary statistics of the main outcome and control variables, and of the measures used to construct the environmental degradation and civic engagement indices. Average donation within our sample was about 550 Leones, and 82.7 percent of participants donated a positive amount to conservation. Turning to survey-based conservation measures, 58 and 50.4 percent of participants said to have taken part, respectively, in town cleaning and water source maintenance over the year prior to the survey. 68 percent of subjects experienced environmental degradation, in the form of increased firewood collection time or income loss due to shocks. On average, 1.41 tokens were donated in the ultimatum game, and about 30.9 percent of participants can be defined as egalitarian according to the index constructed using behavior in the dictator and ultimatum games. The trust index, ranging from a minimum of 0.5 to a maximum of 3 , is on average equal to 1.26 in our sample. The average discount is 66 percent per month. ${ }^{10}$ Finally, the civic engagement index is normally distributed, with a mean of 4 .

[Insert Table 2 here]

\section{Results}

In this section, we investigate the factors behind environmental donation within the experiment, with a special focus on environmental degradation and social preferences. Following the discussion of Section 2, we expect the following correlations to hold: conservation behavior should be positively correlated with dependence on natural resources combined with experience of environmental degradation, altruism, inequality aversion, trust and civic engagement, while it should be decreasing in individuals' discount rate.

\footnotetext{
${ }^{9}$ The conflict exposure index counts the number of ways in which respondents say to have been affected by the war. The list of conflict-related events considered in the survey ranged from having family members killed, injured or abducted, to having one's house burned down, or having had to flee the village because of the war.

${ }^{10}$ Almost 25 percent of participants always preferred to receive money in the present, regardless of how much was offered in the future. Since the discount rate is not defined for these individuals, we drop these observations from the regressions.
} 
Figure 3 reports the percentage of subjects donating $0,300,800$ or 1000 Leones overall (Panel A), depending on whether or not subjects participated in town cleaning and water maintenance; Panel B focuses on subjects who didn't take part in either activity; Panel C on those who took part in either one activity or the other; and Panel D on those who took part in both. In all cases, the distribution of donation amount has a mode at 300 Leones. There is a positive correlation between donation and civic engagement: the percentage of subjects not donating anything is highest among the least engaged individuals and decreases as participation in community conservation activities increases. An opposite pattern can be observed for donations of 1000 Leones.

\section{[Insert Figure 3 here]}

The three measures of environmental conservation are positively correlated, although at differing levels of significance. The correlation is significant between town cleaning and water source maintenance $(\mathrm{p}=.004)$, while it is not between donation and town cleaning $(\mathrm{p}=.720)$ nor between donation and water source maintenance $(\mathrm{p}$ $=.383$ ). These differences in pairwise correlation coefficients suggest that experimental and survey-based outcome variables capture different combinations of civic engagement, social preferences and environmental valuation.

Table 3 shows regression results for the different specifications using donation as the dependent variable. Columns 1 and 3 report (ordered) probit results from equation (2), while 2 and 4 present the OLS results. The exposure-dependence index is constructed using experienced degradation in Columns 1 and 2, and actual deforestation in Columns 3 and 4. All regressions include village fixed-effects, since all of our regressors of interest, and in particular, the exposure-dependence index, vary at the individual level.

[Insert Table 3 here]

Experienced environmental degradation is positively and significantly correlated with conservation behavior within the experiment. The sign and significance of the 
coefficients on the exposure-dependence index is robust to the model used (probit versus OLS) under the first specification. These results support Elinor Ostrom's claim on the effect of dependence and vulnerability to environmental shock being positively correlated with individual willingness to contribute to conservation activities. When actual deforestation rates are used to construct the index, the coefficient on exposure to degradation becomes insignificant.

Among social preferences variables, indicators of altruism and inequality aversion are positively and significantly correlated with donation, as predicted by the theory. More pro-social play and egalitarian choices in the dictator and ultimatum games are associated with higher donations. Survey measures of social preferences, such as time preferences, trust and civic engagement, instead, show no significant correlation with the dependent variable.

Table 4 shows results from similar specifications, with participation in water source maintenance (Columns 1 to 4 ) and participation in town cleaning (Columns 5 to 8 ) as dependent variables. The regressions are run using both non-linear (Columns 1 , 3, 5 and 7) and linear (Columns 1, 3, 5 and 7) models. The exposure-dependence index is constructed using experienced degradation in Columns 1-2 and 5-6, and actual deforestation rates otherwise. The regressions feature, as above, individual controls and village fixed-effects.

[Insert Table 4 here]

Experienced environmental degradation is positively correlated with conservation choices outside the experiment, both with water source maintenance and town cleaning activities. On the contrary, when environmental degradation is measured through actual deforestation, its correlation with conservation behavior is negative and significant. Only a few social preference measures are correlated with conservation behavior outside the experiment. Individual discount rates are negatively and significantly correlated with participation in town cleaning, while higher trust levels translate in significantly higher participation in water source maintenance. None 
of the experimental proxies of social preferences are correlated with the survey measured outcome variables. ${ }^{11}$

Figure 4 shows the value of the three outcome variables for each value of the exposure-dependence index. The level of conservation activities grow as the index increases, though the pattern is less clear for donations. The graph confirms that experienced degradation has a consistent impact across conservation choices, but that there is a significant difference between experimental and survey-based measures of conservation. In general, these results suggest that, within each village, those individuals who are more vulnerable to environmental degradation are also more willing to contribute to the conservation of the environment and maintenance of the common resources.

\section{[Insert Figure 4 here]}

The different results obtained when focusing on experimental versus nonexperimental measures of environmental valuation may be explained, as discussed above, by the fact that the three outcome variables capture different combinations of social preferences related to the environment and more general ones. We thus derive the hypothesis that both types of variables will significantly explain all types of conservation behavior among those individuals who engage in all of them. In order to test this hypothesis, we construct a variable equal to 1 whenever an individual contributed an above-average amount in the experiment, and participated to both town cleaning and water maintenance.

Table 5 reports regression results of the correlation between this indicator of strong preferences for conservation and the usual set of independent variables. The exposure-dependence index is constructed using experienced degradation in Column 1 , and actual deforestation in Column 2.

[Insert Table 5 here]

\footnotetext{
${ }^{11}$ The sign and significance of regression coefficients is confirmed even if we consider each regressor individually, as shown in Appendix tables A1-A3.
} 
The results support our hypothesis and confirm our previous results. Exposure to environmental degradation has a positive effect on conservation when it captures experienced degradation, while it has a negative effect when it reflects past deforestation activities. Experimental measures of social preferences (altruism and inequality aversion) and survey-based measures of social preferences (trust) have a positive and significant effect on the probability of exhibiting strong preferences for conservation. When individual preferences for conservation are strong along all dimensions, experimental and survey based measures of various social preferences are significantly correlated with conservation behavior. Our results are closest to the theoretical predictions derived from the literature for individuals with strong preferences for conservation.

Finally, we test whether donations differ depending on treatment assignment. No significant difference in average donation is observed ${ }^{12}$. This is confirmed by regression results reported in the Appendix (Table A4). There, we regress donation amount on interaction terms between each of the social preference independent variables and a dummy equal to 1 if a subject was assigned to the in-group treatment. Being told that the NGO's activity will benefit people from one's own region doesn't increase donations: the coefficients on the in-group variable are generally insignificant and switch sign depending on the specification. None of the interaction terms are significant, implying that none of the dimensions of social preferences examined here lead to increased donations for conservation when the benefits are perceived to be directed to one's own community.

\section{Discussion}

All the most often cited determinants of conservation behavior are explored in this study, and our main result is that the experience of environmental degradation in rural Sierra Leone makes individuals more likely to support conservation. Within each village, those most exposed to the consequences of deforestation are also more willing

\footnotetext{
${ }^{12}$ We run a Wilcoxon rank-sum test of the equality of distribution by treatment, which confirms the lack of significant differences between in-group and out-group $(\mathrm{p}=.285)$.
} 
to contribute to conservation. On the other hand, living within a village where deforestation was conducted is not by itself conducive to higher valuation of the environment. This result is probably due to the fact that the deforestation measure captures, besides exposure, the effect of low valuation of the environment in the past, which is likely to persist in the present and be among the determinants of individual current conservation behavior. The correlation between past and present low valuation of the environment may offset the positive effect of exposure to degradation on conservation choices. The issue of endogeneity does not only affect our measure of exposure based on deforestation. Experienced degradation may also suffer from endogeneity, since it may be correlated with individual characteristics that also influence conservation choices.

Keeping these caveats in mind, the results on exposure to degradation are overall consistent with Elinor Ostrom's claim that conservation behavior is fostered by a combination of worsening environmental conditions and dependence on natural resources. And, furthermore, the results also show that living with the consequences of overexploitation of common resources is not enough to raise individual preferences for the environment.

The findings of our study suggest that there is potential for sustainable natural resource use in an extremely poor, rural, and environmentally degraded setting. We show that willingness to contribute to conservation may require awareness of the consequences of environmental degradation, and that this awareness is positively associated with conservation behavior. We show this through our findings that perceived environmental degradation varies within villages even though actual degradation does not. Environmental education, by disseminating information on the costs of environmental degradation, may therefore be effectively used to build support for locally-owned conservation initiatives, even in very poor settings. Since many development pathways are critically dependent upon the maintenance and exploitation of natural resources, this research is critical for policy makers seeking to manage developing countries' resources. Consistent with these policy implications, the donations collected through our experiment were used by CSSL to offer environmental education across villages in the study area. CSSL's environmental campaign focused 
on the consequences of bush fires, and procedures needed to minimize deforestation due to slash-and-burn agriculture.

The second main result of this study is methodological. We observe lack of correlation between experimental and survey measures of conservation. We find that, while donations are significantly correlated with experimental proxies of social preferences, they have no significant relationship with survey-based ones. In contrast, real-world conservation behavior is not explained by experimentally measured social preferences, but by survey-measured ones. The lack of correlation between experimental indices of social preferences and survey measures of conservation is consistent with psychology studies (Lee and Nisbett, 1991) and with Voors et al. (2011). Consistent with previous literature is also our finding that more abstract measures of social preferences are unable to account for behavior in the real world, similar to the findings of Voors et al. (2011). However, both types of measures are significantly correlated with conservation behavior when we define the latter as scoring high along both experimental and real world conservation decisions. Finally, also in contrast with Voors et al. (2011), we find survey-based measure of experienced environmental degradation to be significantly correlated with conservation behavior both within and outside the experiment.

To reconcile these two sets of findings, it is important to note that, where a strong connection between experimental and real world decisions exists, as in the case of our donation task, behavior is consistent across realms. The lack of correlation between behavior within and outside the experiment is the result of experimental designs that do not closely reproduce real world decision environments. Indeed, the experiment we employed may be thought of as a modified version of a public goods game, where CSSL represents the environmental public good. An important distinction of this modified version is that it more closely mirrors the real world, where the time of repayment and distribution to the public pool is unknown. The experimental choice adopted in our study involved a loss of control relative to the use of standard public good games, but this cost was outweighed by the possibility of drawing policy lessons from our results. Our research informs policy makers that the generalizability of laboratory findings in a 
field setting crucially relies on the experimental design mirroring real world conditions.

\section{Conclusions}

Using survey-based and experimental measures of conservation behavior and social preferences, this study investigates factors correlated with preferences for the environment. We find that, when dependence on natural resources is high, suffering the consequences of environmental degradation is positively correlated with both participants' willingness to support environmental organizations and their likelihood of engaging in conservation activities. Simply living in areas which have experienced environmental degradation is not sufficient to raise people's valuation of the environment. On the contrary, the weak preferences for conservation that have led to overexploitation of forest resources in the past appear to persist in current conservation choices. Experimental proxies of social preferences are correlated with donations, but not with actual conservation activities. The opposite holds for surveybased measures of social preferences, which explain environmental valuation outside but not within the experiment.

These findings are consistent with the existing literature on CPR management and social preferences. They also allow us to make a methodological point concerning the possibility to draw policy lessons from experimental findings: in order to generalize behavior from the laboratory to the field, experimental designs need to be carefully tailored to the decision setting and actual behavior one wishes to explain. In our case, the results show the importance of environmental awareness in fostering conservation choices, and point to the role of environmental education messages explaining the costs of natural resource misuse.

An interesting follow-up to this study would explore the effect of education campaigns on participants' conservation behavior. In light of the findings from this study, environmental education programs are likely to have profound implications for the livelihood of individuals living in areas subject to natural resource depletion in developing countries. A second extension to this paper would address its main limitations, due to available measures of environmental degradation. In the future, we 
plan to identify exogenous sources of environmental degradation within the study area, in order to explore the causal effect of environmental degradation on conservation behavior. 


\section{References}

Agrawal, A. (2001). Common Property Institutions and Sustainable Governance of Resources. World Development, 29, 1649-1672.

Andreoni, J., Harbaugh, W., \& Vesterlund, L. (2003). The Carrot or the Stick: Rewards, Punishments, and Cooperation. The American Economic Review , 93 (3), 893-902. Baland, J.-M., \& Platteau, J.-P. (1996). Halting Degradation of Natural Resources: is there a role for Rural Communities? Rome, Italy: Food and Agriculture Organization. Bardhan, P. (2000). Irrigation and Cooperation: An Empirical Analysis of 48 Irrigation Communities in South India. Economic Development and Cultural Change , 48 (4), 847865.

Bauer, M., Cassar, A., Chytilova, J., \& Henrich, J. (2011). Warfare Increases Egalitarian and Parochial Motivations in Children. Working Paper .

Becker, G. S. (1976). Altruism, Egoism, and Genetic Fitness: Economics and Sociobiology. Journal of Economic Literature , 14 (3), 817-826.

Bégue, L., \& Hafer, C. L. (2005). Experimental Research on Just-World Theory: Problems, Developments, and Future Challenges. Psychological Bulletin , 131 (1), 128167.

Bizzarri, M. (2009). Safe Access to Firewood and Alternative Energy in North Darfur: An Appraisal Report. Rome: World Food Programme.

Bouma, J., Bulte, E., \& van Soest, D. (2008). Trust and Cooperation: Social capital and community resource management. Journal of Environmental Economics and Management, 56 (2), 155-166.

Bucknall, J., Kraus, C., \& Pillai, P. (2000). Poverty and the Environment. World Bank. Camerer, C.F. (2003). Behavioral Game Theory: Experiments in Strategic Interaction. Princeton: Princeton University Press.

Cameron, C. \& Miller, D. (2010), Robust Inference with Clustered Data, Working Paper 106, UC Davis.

Chavez, P. S. (1996). Image-based atmospheric corrections - Revisited and improved. Photogrammetric Engineering \& Remote Sensing , 62 (9), 1025-1036. 
Collard, D. A. (1978). Altruism and Economy: A Study in Non-selfish Economics. New York: Oxford University Press.

Conservation Society of Sierra Leone. (n.d.). Retrieved from http://conservationsl.org. Cramb, R. A. (2005). Social capital and soil conservation: evidence from the Philippines. Australian Journal of Agriculture and Resource Economics , 49 (2), 211-226. d'Adda G., (2011a). Motivation Crowding in Environmental Protection: Evidence from an Artefactual Field Experiment. Ecological Economics, forthcoming. d'Adda G., (2011b). Social Status and Influence: Evidence from an Local Public Good Provision. Working Paper.

Diekmann, A. and Preisendörfer, P. (2003). Green and greenback: The behavioral effects of environmental attitudes in low-cost and high-cost situations. Rationality and Society, 15(4), 441-472.

Dietz, T., Ostrom, E., \& Stern,P. (2003). The Struggle to Govern the Commons. Science, 302, 1907-1912.

Fehr, E., Bernhard, H. \& Rockenbach, B. (2008). Egalitarianism in Young Children. Nature, 454, 1079-1083.

Gächter, S., Herrmann, B., \& Thöni, C. (2004). Trust, voluntary cooperation, and socioeconomic background: survey and experimetal evidence. Journal of Economic Behavior \& Organization, 55 (4), 505-531.

Gibson, C.C., Williams, J.T., \& Ostrom, E. (2005). Local Enforcement and Better Forests. World Development, 33, 273-284.

Goeree, J. K., Holt, C. A., \& Laury, S. K. (2002). Private costs and public benefits: unraveling the effects of altruism and noisy behavior. Journal of Public Economics , 83 (2), 255-276.

Hardin, G. (1968). The Tragedy of the Commons. Science , 162, 1243-1248. Harrison, G.W., \& List J.A., (2004). Field Experiments. Journal of Economic Literature, $17,1009-1055$.

Holden, S. T., Shiferaw, B., \& Wik, M. (1998). Povert, market imperfections, and time preferences: of relevance for environmental policy? Environment and Development Economics , 3 (1), 105-130. 
Human Development Report. (2010). Retrieved from

http://hdr.undp.org/en/statistics/.

Jumbe, C. B., \& Angelson, A. (2007). Forest Dependence and Participation in CPR Management: Empirical Evidence from Forest co-management in Malawi. Ecological Economics , 62, 661-672.

Kremer, M., Leino, J., Miguel, E., \& Zwane, A. (2011). Spring Cleaning: Rural Water Impacts, Valuation, and Property Rights Institutions. The Quarterly Journal of Economics, 126 (1), 145-205.

Lee, R., \& Nisbett, R.E., (1991). The Person and the Situation: Perspectives of Social Psychology. New York: McGraw-Hill.

Lerner, M. J. (1980). The belief in a just world: A fundamental delusion. New York: Plenum Press.

Mendelsohn, R., Dinar, A., \& Williams, L. (2006). The distributional impact of climate change on rich and poor countries. Environment and Development Economics, 2, 159178.

Millennium Ecosystem Assessment (2005). Ecosystems and human well-being: biodiversity synthesis. World Resources Institute, Washington, DC.

Morton, J. (2007). The impact of climate change on smallholder and subsistence agriculture. PNAS, 104(50), 19680-19685.

Moseley, W. G. (2001). African evidence on the relation of poverty, time preferences, and the environment. Ecological Economics , 38 (3), 317-326.

Nankhuni, F. J., \& Findeis, J. L. (2004). Natural resource-collection work and children's schooling in Malawi. Agricultural Economics , 31 (2-3), 123-134.

Narayan, D. (1999). Bonds and Bridges: Social Capital and Poverty. New York: World Bank.

Nelson, V., Meadows, K., Cannon, T., Morton, J., \& Martin, A. (2002). Uncertain Predictions, Invisible Impacts, and the Need to Mainstream Gender in Climate Change Adaptations. Gender and Development, 10(2), 51-59.

Ostrom, E. (1998). A Behavioral Approach to the Rational Choice Theory of Collective Action: Presidential Address, American Political Science Association, 1997. The American Political Science Review , 92 (1), 1-22. 
Ostrom, E. (1999). Self Governance and Forest Resources. Jakarta, Indonesia: Center for International Forestry Research.

Ostrom, E., Burger, J., Field, C. B., Norgaard, R. B., \& Policansky, D. (1999). Revisiting the Commons: Local Lessons, Global Challenges. Science , 284, 278-282.

Poortinga, W., Steg, L., and Vlek, C. (2004). Values, environmental concern and environmental behavior. Environment and Behavior, 36(1):70-93.

Pretty, J. (2003). Social Capital and the Collective Management of Resources. Science, 302 (5652), 1912-1914.

Pretty, J., \& Smith, D. (2004). Social Capital in Biodiversity Conservation and Management. Conservation Biology , 18 (3), 631-638.

Reece, W. (1979). Charitable contributions: New evidence on household behavior. The American Economic Review.

Squire, C. B. (2001). Sierra Leone's Biodiversity and the Civil War: A Case Study Prepared for the Biodiversity Support Program. Washington, D.C.: Biodiversity Support Program.

Stern, N. (2006). What is the Economics of Climate Change? World Development, 7(2), 1-10.

TEEB (2010). The Economics of Ecosystems and Biodiversity: Mainstreaming the Economics of Nature: A synthesis of the approach, conclusions and recommendations of TEEB.

Voors, M., Bulte, E., List, J. A., Kontoleon, A., \& Turley, T. (2011). Using Artefactual Field Experiments to Learn about the Incentives for Sustainable Forest Use in Developing Economies. Working Paper .

Wade, R. (1987). The Management of Common Property Resources: Collective Action as an Alternative to Privatization or State Regulation. Cambridge Journal of Economics, 11, 95-106.

Wakefield, S. E., Elliott, S. J., \& Cole, D. C. (2007). Social capital, environmental health and collective action: a Hamilton, Ontario case study. Canadian Geographer , 51 (4), 428-443. 
Walker, J., \& Ostrom, E. (2007). Trust and Reciprocity as Foundations for Cooperation: Individuals, Institutions, and Context. Capstone Meeting of the RSF Trust Initiative. Russell Sage Foundation. 


\section{Tables and Figures}

Figure 1. Ecological Footprint (red) and biocapacity (green) of Sierra Leone, 1961-

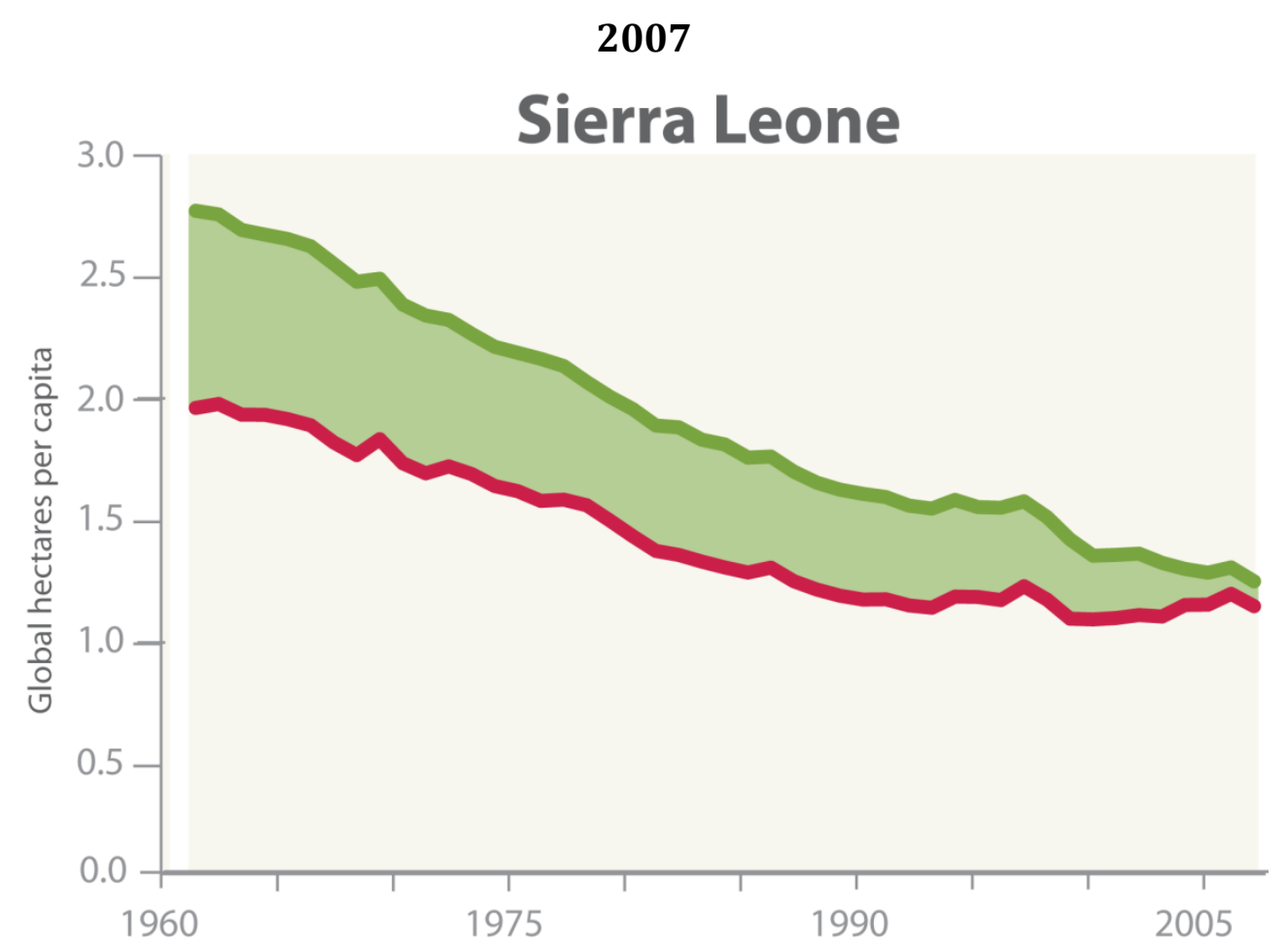

Note: The Ecological Footprint of production represents the rate of resource extraction and waste generation; biocapacity represents the rate of resource re-generation and waste sequestration. A situation where the Ecological Footprint exceeds biocapacity indicates that domestic resources may be degraded. Sierra Leone seems to be approaching this point, and may cross it within a few years if there are no conservation efforts (Ewing, Moore, Goldfinger, Oursler, Reed, \& Wackernagel, 2010). 
Figure 2. GIS Maps of Forest Cover in Study Area: 1991, 2006 and 2010

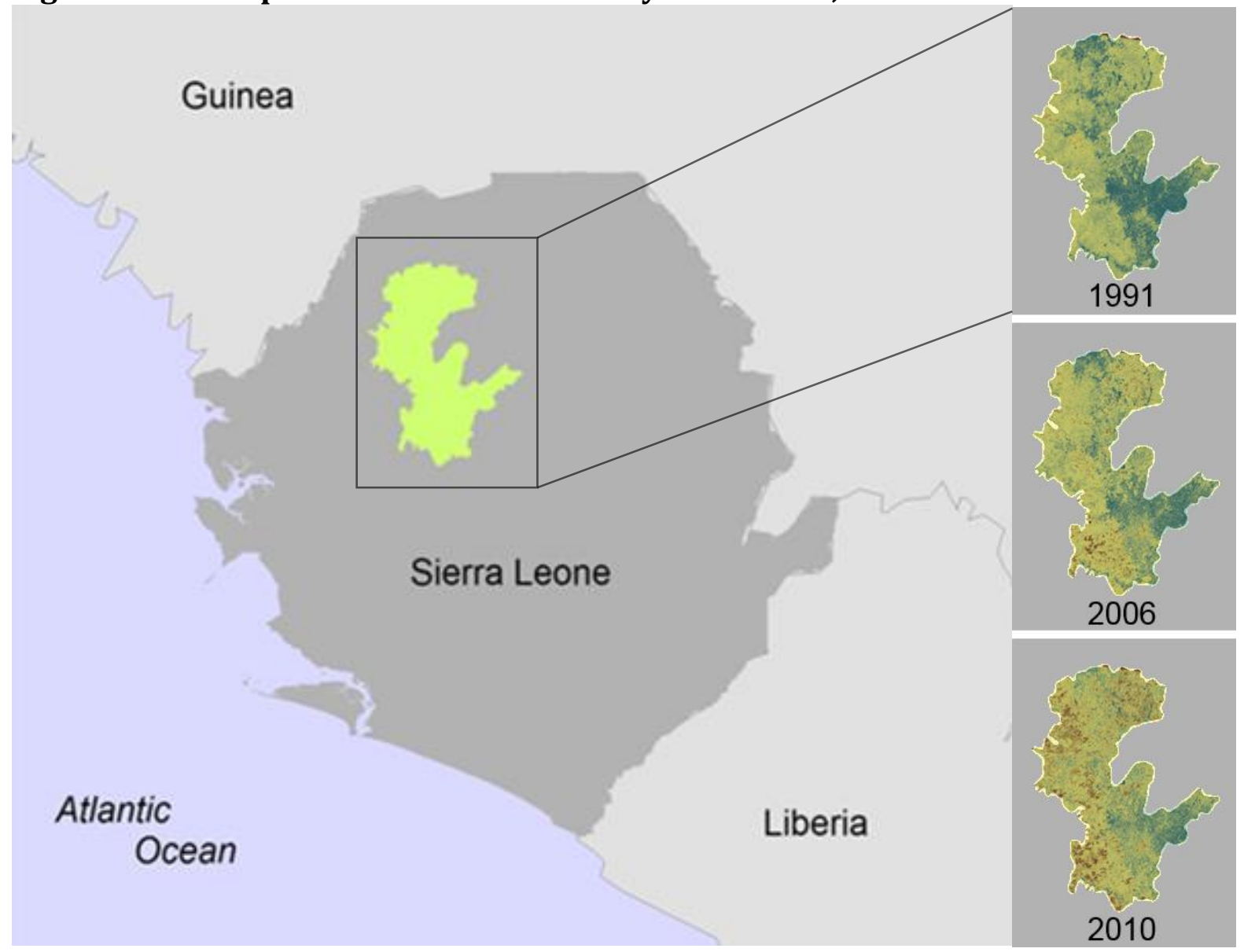

Note: Maps show the soil-adjusted vegetation index (SAVI): dark green areas represent the highest vegetation cover; redbrown areas represent bare ground. Source: NASA Landsat Program, 2010. ETM+ and TM. Bands 3 and 4. 
Figure 3. Distribution of donations: frequency of donation amounts

a. Overall

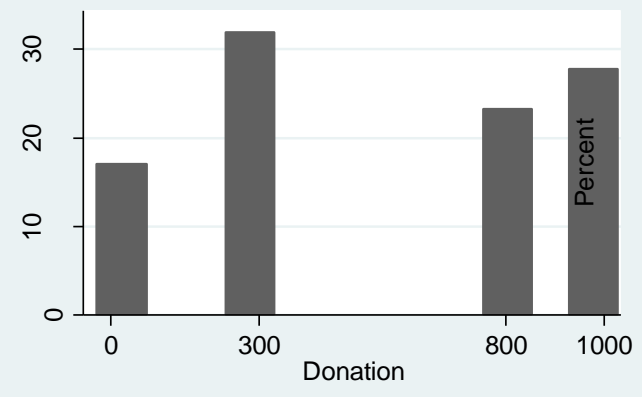

c. Either

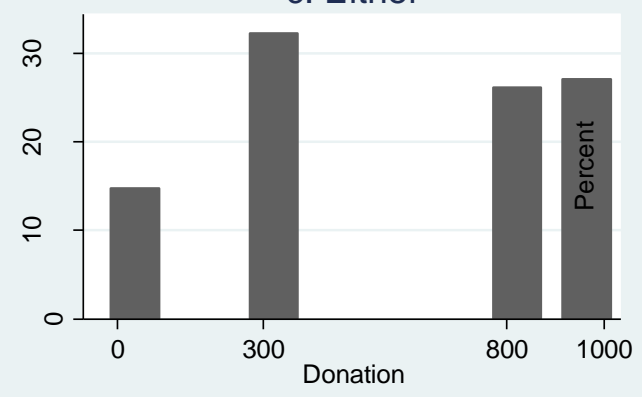

b. Neither

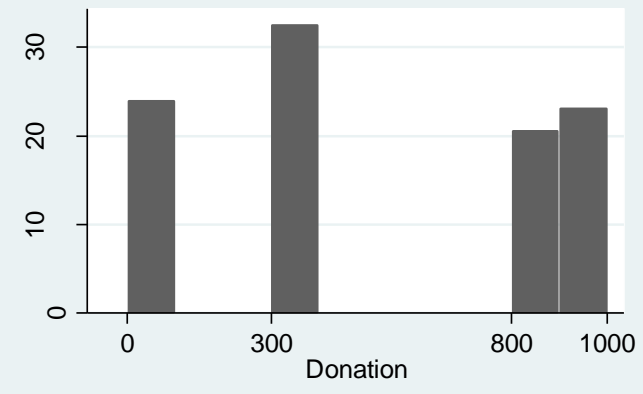

d. Both

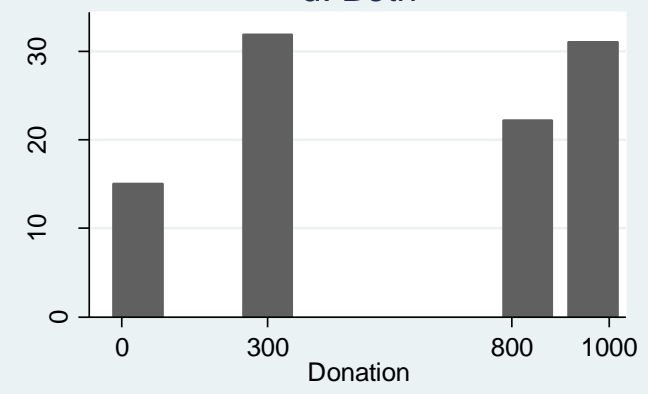

Note: Percentages reported. Panel a reports distribution of donation over all subjects, Panel b over subjects who did not participate in town cleaning or water maintenance, Panel c over subjects who participated in either of the two activities, Panel d over subjects who participated in both activities. 
Figure 4. Exposure to environmental degradation-dependence on natural resources and on conservation choices

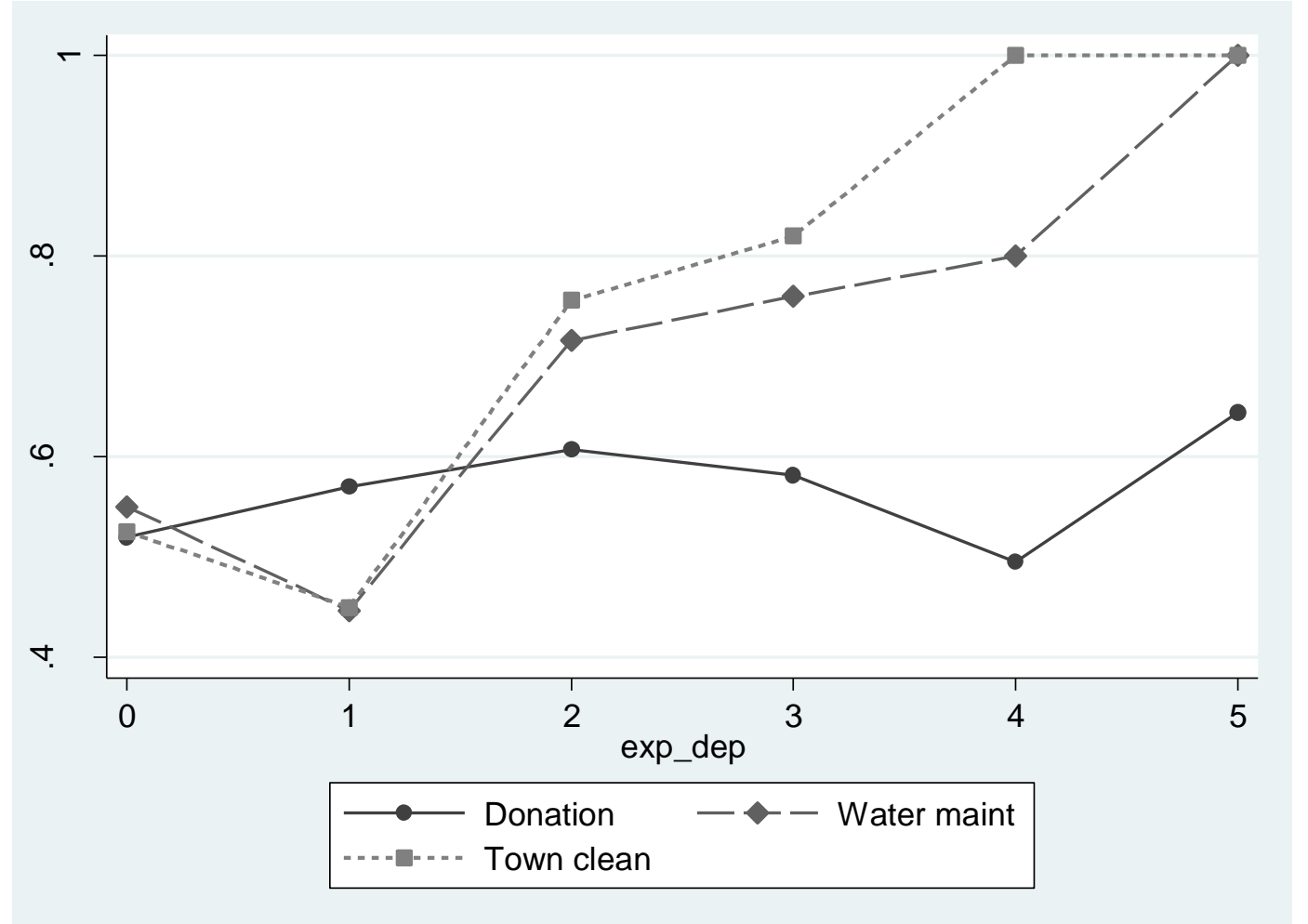

Note: Donation amount expressed in thousands in order to use the same scale as for the water maintenance and town cleaning dummy variables. 
Table 1. Summary statistics

\begin{tabular}{lcc}
\hline Variable & Mean & Std. Dev. \\
\hline \hline Age & 40.76 & 13.70 \\
Female & .69 & .46 \\
Married & .79 & .40 \\
Christian & .34 & .47 \\
Temne & .65 & .48 \\
Household size & 9.01 & 4.38 \\
Attended school & .26 & .44 \\
Total weekly expenditure per capita (/000 & & \\
Leones) & 49.46 & 59.25 \\
Owns land & .77 & .42 \\
Farmer & .75 & .43 \\
Years living in village & 25.98 & 17.94 \\
Suffered from health shocks over the past year & .49 & .50 \\
Uses forest products & .90 & .29 \\
Time to collect firewood (in minutes) & 89.04 & 52.21 \\
Thinks there are environmental problems & .99 & .07 \\
Forced to flee during war & .87 & .34 \\
Number of conflict-related events suffered & 5.31 & 1.57 \\
\hline
\end{tabular}


Table 2. Dependent variables and regressors of interest: summary statistics

\begin{tabular}{|c|c|c|}
\hline Variable & Mean & Std. Dev. \\
\hline \multicolumn{3}{|l|}{ Conservation behavior } \\
\hline Donation to CSSL & 559.86 & 377.37 \\
\hline Participated in water source maintenance over the previous year & .59 & .49 \\
\hline Participated in road brushing over the previous year & .60 & .49 \\
\hline Strong revealed preferences for conservationa & .21 & .41 \\
\hline \multicolumn{3}{|c|}{ Perceived environmental degradation index and variables used to construct it } \\
\hline Perceived environmental degradation index & .68 & .47 \\
\hline Suffered from environmental shocks over the past 3 years & .37 & .48 \\
\hline Time to collect firewood increased over past 2 years & .37 & .48 \\
\hline \multicolumn{3}{|l|}{ Social preferences } \\
\hline Ratio of personal to general trust & 1.26 & .51 \\
\hline Discount rate & 65.86 & 49.24 \\
\hline Inequality averse & .09 & .29 \\
\hline Strong egalitarian & .31 & .46 \\
\hline Weak egalitarian & .61 & .49 \\
\hline Dictator game giving (number of tokens sent) & 1.41 & 1.22 \\
\hline Ultimatum game giving (number of tokens sent) & 1.78 & 1.00 \\
\hline \multicolumn{3}{|l|}{ Civic engagement index and variables used to construct it } \\
\hline Civic engagement index & 4.00 & 1.08 \\
\hline Number of community meetings attended over the previous year & 5.77 & 4.46 \\
\hline Member of Parents-Teachers group & .71 & .45 \\
\hline Member of Village Development committee & .22 & .41 \\
\hline Member of credit group & .24 & .43 \\
\hline Member of labor sharing group & .50 & .50 \\
\hline Member of social group & .29 & .45 \\
\hline Member of religious group & .51 & .50 \\
\hline Member of saving group & .28 & .45 \\
\hline Member of traditional society & .39 & .49 \\
\hline Voted in past general elections & .97 & .17 \\
\hline Voted in past local elections & .93 & .26 \\
\hline
\end{tabular}

Note: a Defined as above-average donation amount, and participation in both town cleaning and road brushing 
Table 3. Determinants of donation amount

\begin{tabular}{|c|c|c|c|c|}
\hline & \multicolumn{4}{|c|}{ Dependent variable: Donation amount } \\
\hline & $\begin{array}{c}\text { Subjective } \\
\text { exposure to } \\
\text { degradation } \\
\text { (oprobit) }\end{array}$ & $\begin{array}{c}\text { Subjective } \\
\text { exposure to } \\
\text { degradation } \\
\text { (OLS) }\end{array}$ & $\begin{array}{c}\text { Objective } \\
\text { exposure to } \\
\text { degradation } \\
\text { (oprobit) }\end{array}$ & $\begin{array}{c}\text { Objective } \\
\text { exposure to } \\
\text { degradation } \\
\text { (OLS) }\end{array}$ \\
\hline & (1) & (2) & (3) & (4) \\
\hline Exposure-dependence index & $0.128^{* *}$ & $37.410^{*}$ & & \\
\hline (experienced degradation) & $(0.056)$ & $(17.961)$ & & \\
\hline Exposure-dependence index & & & -1580.202 & $-6.36 e+05$ \\
\hline (actual deforestation) & & & $(2535.690)$ & $(7.33 e+05)$ \\
\hline \multirow[t]{2}{*}{ Altruism } & $0.214^{* * *}$ & $69.791^{* * *}$ & $0.246^{* * *}$ & $76.679^{* * *}$ \\
\hline & $(0.064)$ & $(18.525)$ & $(0.070)$ & $(19.451)$ \\
\hline \multirow[t]{2}{*}{ Strong egalitarian } & $0.426^{* * *}$ & $142.754^{* * *}$ & $0.372^{* *}$ & $138.888^{* *}$ \\
\hline & $(0.152)$ & $(47.688)$ & $(0.176)$ & $(54.037)$ \\
\hline \multirow[t]{2}{*}{ Discount rate } & 0.001 & 0.122 & 0.001 & 0.155 \\
\hline & $(0.001)$ & $(0.347)$ & $(0.001)$ & $(0.384)$ \\
\hline Personal to general trust & 0.011 & 9.847 & 0.083 & 33.711 \\
\hline ratio & $(0.134)$ & $(44.642)$ & $(0.143)$ & $(46.994)$ \\
\hline \multirow[t]{2}{*}{ Civic engagement } & -0.059 & -20.607 & -0.051 & -22.077 \\
\hline & $(0.073)$ & $(23.228)$ & $(0.073)$ & $(20.092)$ \\
\hline Individual controls & $\mathrm{x}$ & $\mathrm{x}$ & $\mathrm{x}$ & $\mathrm{x}$ \\
\hline Village fixed-effects & $\mathrm{x}$ & $\mathrm{x}$ & $\mathrm{x}$ & $\mathrm{x}$ \\
\hline Observations & 339 & 339 & 303 & 303 \\
\hline (Pseudo) R-squared & 0.089 & 0.234 & 0.091 & 0.248 \\
\hline Number of clusters & 21 & 21 & 19 & 19 \\
\hline
\end{tabular}


Table 4. Determinants of conservation behavior

\begin{tabular}{|c|c|c|c|c|c|c|c|c|}
\hline & \multicolumn{8}{|c|}{ Dependent variable } \\
\hline & $\begin{array}{c}\text { Water } \\
\text { maintenance } \\
\text { (probit) } \\
\text { (1) }\end{array}$ & $\begin{array}{c}\text { Water } \\
\text { maintenance } \\
(O L S) \\
(2)\end{array}$ & $\begin{array}{c}\text { Water } \\
\text { maintenance } \\
\text { (probit) } \\
\text { (3) }\end{array}$ & $\begin{array}{c}\text { Water } \\
\text { maintenance } \\
(O L S) \\
(4)\end{array}$ & $\begin{array}{c}\text { Townclean } \\
\text { (probit) } \\
\text { (5) }\end{array}$ & $\begin{array}{c}\text { Townclean } \\
\text { (OLS) } \\
(6)\end{array}$ & $\begin{array}{c}\text { Townclean } \\
\text { (probit) } \\
\text { (7) }\end{array}$ & $\begin{array}{l}\text { Townclean } \\
\text { (OLS) } \\
(8)\end{array}$ \\
\hline \multicolumn{9}{|l|}{ Exposure-dependence } \\
\hline index & $0.317^{* * *}$ & $0.076^{* * *}$ & & & $0.392^{* * *}$ & $0.066^{* * *}$ & & \\
\hline (experienced degradation) & $(0.072)$ & $(0.018)$ & & & $(0.093)$ & $(0.019)$ & & \\
\hline \multicolumn{9}{|l|}{ Exposure-dependence } \\
\hline index & & & $-1.16 \mathrm{e}+04^{* * *}$ & $-2437.858^{* *}$ & & & $-1.92 \mathrm{e}+04^{* * *}$ & $-3073.957^{* *}$ \\
\hline (actual deforestation) & & & $(3924.641)$ & $(894.012)$ & & & $(6347.065)$ & $(1110.635)$ \\
\hline \multirow[t]{2}{*}{ Altruism } & -0.025 & -0.004 & -0.054 & -0.010 & -0.034 & -0.001 & -0.032 & 0.003 \\
\hline & $(0.088)$ & $(0.023)$ & $(0.093)$ & $(0.026)$ & $(0.101)$ & $(0.025)$ & $(0.095)$ & $(0.027)$ \\
\hline \multirow[t]{2}{*}{ Strong egalitarian } & -0.107 & -0.018 & -0.090 & -0.023 & 0.206 & 0.044 & 0.142 & 0.026 \\
\hline & $(0.198)$ & $(0.055)$ & $(0.192)$ & $(0.052)$ & $(0.217)$ & $(0.046)$ & $(0.213)$ & $(0.054)$ \\
\hline \multirow[t]{2}{*}{ Discount rate } & -0.002 & -0.001 & -0.002 & -0.001 & $-0.006^{* * *}$ & $-0.001^{* *}$ & $-0.005^{* *}$ & $-0.002^{* *}$ \\
\hline & $(0.002)$ & $(0.000)$ & $(0.002)$ & $(0.001)$ & $(0.002)$ & $(0.001)$ & $(0.002)$ & $(0.001)$ \\
\hline \multirow{2}{*}{$\begin{array}{l}\text { Personal to general trust } \\
\text { ratio }\end{array}$} & $1.052^{* *}$ & $0.238^{* * *}$ & $1.086^{* *}$ & $0.251^{* * *}$ & 0.212 & 0.063 & 0.315 & 0.083 \\
\hline & $(0.450)$ & $(0.064)$ & $(0.464)$ & $(0.072)$ & $(0.238)$ & $(0.043)$ & $(0.242)$ & $(0.052)$ \\
\hline \multirow{2}{*}{ Civic engagement } & 0.052 & 0.015 & 0.119 & 0.037 & $0.256^{*}$ & 0.045 & 0.249 & 0.051 \\
\hline & $(0.077)$ & $(0.022)$ & $(0.092)$ & $(0.026)$ & $(0.152)$ & $(0.031)$ & $(0.152)$ & $(0.031)$ \\
\hline Individual controls & $\mathrm{x}$ & $\mathrm{x}$ & $\mathrm{x}$ & $\mathrm{x}$ & $\mathrm{x}$ & $\mathrm{x}$ & $\mathrm{x}$ & $\mathrm{x}$ \\
\hline Village fixed-effects & $\mathrm{x}$ & $\mathrm{x}$ & $\mathrm{x}$ & $\mathrm{x}$ & $\mathrm{x}$ & $\mathrm{x}$ & $\mathrm{x}$ & $\mathrm{x}$ \\
\hline Observations & 337 & 337 & 301 & 301 & 338 & 338 & 302 & 302 \\
\hline (Pseudo) R-squared & 0.329 & 0.355 & 0.324 & 0.356 & 0.413 & 0.409 & 0.392 & 0.401 \\
\hline Number of clusters & 21 & 21 & 19 & 19 & 21 & 21 & 19 & 19 \\
\hline
\end{tabular}

Notes. Individual controls: ingroup treatment, age, gender, education, religion, marital status, ethnicity, household per capita expenditure, household size, number of years spent in the village. Observations clustered at the village level. 
Table 5. Determinants of strong preferences for conservation

\begin{tabular}{|c|c|c|}
\hline & \multicolumn{2}{|c|}{ Dependent variable } \\
\hline & \multicolumn{2}{|c|}{ Strong preferences for conservation } \\
\hline & (1) & (2) \\
\hline $\begin{array}{l}\text { Exposure-dependence index } \\
\text { (experienced degradation) }\end{array}$ & $\begin{array}{c}0.291 * * * \\
(0.072)\end{array}$ & \\
\hline $\begin{array}{l}\text { Exposure-dependence index } \\
\text { (actual deforestation) }\end{array}$ & & $\begin{array}{c}-1.58 \mathrm{e}+04^{* * *} \\
(4960.660)\end{array}$ \\
\hline Altruism & $\begin{array}{l}0.222^{* *} \\
(0.110)\end{array}$ & $\begin{array}{l}0.213^{*} \\
(0.126)\end{array}$ \\
\hline Strong egalitarian & $\begin{array}{l}0.473^{* *} \\
(0.197)\end{array}$ & $\begin{array}{c}0.651^{* * *} \\
(0.181)\end{array}$ \\
\hline Discount rate & $\begin{array}{c}0.001 \\
(0.002)\end{array}$ & $\begin{array}{c}0.001 \\
(0.002)\end{array}$ \\
\hline $\begin{array}{l}\text { Personal to general trust } \\
\text { ratio }\end{array}$ & $\begin{array}{c}0.641^{* * *} \\
(0.223)\end{array}$ & $\begin{array}{c}0.783^{* * *} \\
(0.244)\end{array}$ \\
\hline Civic engagement & $\begin{array}{c}0.001 \\
(0.110)\end{array}$ & $\begin{array}{c}0.021 \\
(0.114)\end{array}$ \\
\hline Individual controls & $\mathrm{x}$ & $\mathrm{x}$ \\
\hline Village fixed-effects & $\mathrm{x}$ & $\mathrm{x}$ \\
\hline Observations & 324 & 288 \\
\hline Pseudo R-Squared & 0.242 & 0.271 \\
\hline Number of clusters & 20 & 18 \\
\hline
\end{tabular}

Notes. GIS deforestation: village deforestation rate. Individual controls: ingroup treatment, age, gender, education, religion, marital status, ethnicity, household per capita expenditure, household size, number of years spent in the village. Observations clustered at the village level. 


\section{Appendix A}

Table A1. Social preferences and donation

\begin{tabular}{|c|c|c|c|c|c|c|}
\hline & \multicolumn{6}{|c|}{ Dependent variable: } \\
\hline & $\begin{array}{l}\text { Donation } \\
\text { (oprobit) }\end{array}$ & $\begin{array}{l}\text { Donation } \\
\text { (oprobit) }\end{array}$ & $\begin{array}{l}\text { Donation } \\
\text { (oprobit) }\end{array}$ & $\begin{array}{l}\text { Donation } \\
\text { (oprobit) }\end{array}$ & $\begin{array}{l}\text { Donation } \\
\text { (oprobit) }\end{array}$ & $\begin{array}{l}\text { Donation } \\
\text { (oprobit) }\end{array}$ \\
\hline & $(1)$ & $(2)$ & $(3)$ & $(4)$ & (5) & $(6)$ \\
\hline $\begin{array}{l}\text { Exposure-dependence index } \\
\text { (experienced degradation) }\end{array}$ & $\begin{array}{l}0.128 * * \\
(0.063)\end{array}$ & & & & & \\
\hline Altruism & & $\begin{array}{l}0.191^{* * *} \\
(0.044)\end{array}$ & & & & \\
\hline Strong egalitarian & & & $\begin{array}{l}0.468^{* * *} \\
(0.113)\end{array}$ & & & \\
\hline Discount rate & & & & $\begin{array}{c}0.000 \\
(0.001)\end{array}$ & & \\
\hline Personal to general trust ratio & & & & & $\begin{array}{c}0.025 \\
(0.105)\end{array}$ & \\
\hline Civic engagement & & & & & & $\begin{array}{c}0.061 \\
(0.049)\end{array}$ \\
\hline Individual controls & $\mathrm{x}$ & $\mathrm{x}$ & $\mathrm{x}$ & $\mathrm{x}$ & $\mathrm{x}$ & $\mathrm{x}$ \\
\hline Village fixed-effects & $\mathrm{x}$ & $\mathrm{x}$ & $\mathrm{x}$ & $\mathrm{x}$ & $\mathrm{x}$ & $\mathrm{x}$ \\
\hline Observations & 516 & 548 & 553 & 414 & 553 & 540 \\
\hline (Pseudo) R-squared & 0.038 & 0.047 & 0.045 & 0.039 & 0.032 & 0.033 \\
\hline Number of clusters & 21 & 21 & 21 & 21 & 21 & 21 \\
\hline
\end{tabular}

Notes. Individual controls: ingroup treatment, age, gender, education, religion, marital status, ethnicity, household per capita expenditure, household size, number of years spent in the village. Observations clustered at the village level. 
Table A2. Social preferences and water source maintenance

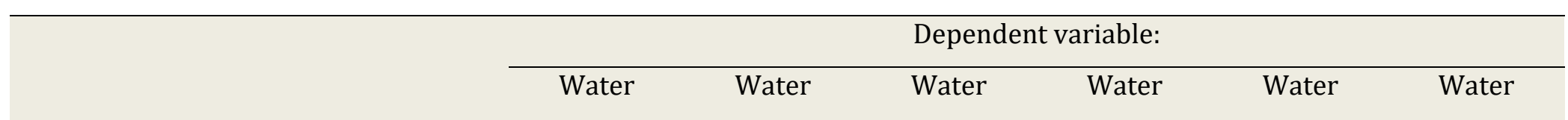

maintenance maintenance maintenance maintenance maintenance maintenance

\begin{tabular}{cccccccc} 
& (probit) & (probit) & (probit) & (probit) & (probit) & (probit) \\
\hline & $(1)$ & $(2)$ & $(3)$ & $(4)$ & $(5)$ & $(6)$ & $(6)$ \\
\hline
\end{tabular}

Exposure-dependence index

(experienced degradation)

Altruism

Strong egalitarian

Discount rate

Personal to general trust ratio

Civic engagement

$0.724^{* * *}$

$(0.140)$

0.010
$(0.040)$

$(0.040)$
0.048

(0.146)

$\begin{array}{lcccccc}\text { Civic engagement } & & & & & & 0.271^{* * *} \\ & & & & & & \\ (0.072)\end{array}$
Notes. Individual controls: ingroup treatment, age, gender, education, religion, marital status, ethnicity, household per capita expenditure, household size, number
of years spent in the village. Observations clustered at the village level. 
Table A3. Social preferences and town cleaning

\begin{tabular}{|c|c|c|c|c|c|c|}
\hline & & & Depende & variable: & & \\
\hline & $\begin{array}{c}\text { Townclean } \\
\text { (probit) }\end{array}$ & $\begin{array}{c}\text { Townclean } \\
\text { (probit) }\end{array}$ & $\begin{array}{c}\text { Townclean } \\
\text { (probit) }\end{array}$ & $\begin{array}{c}\text { Townclean } \\
\text { (probit) }\end{array}$ & $\begin{array}{c}\text { Townclean } \\
\text { (probit) }\end{array}$ & $\begin{array}{c}\text { Townclean } \\
\text { (probit) }\end{array}$ \\
\hline & (1) & (2) & (3) & (4) & (5) & (6) \\
\hline $\begin{array}{l}\text { Exposure-dependence index } \\
\text { (experienced degradation) }\end{array}$ & $\begin{array}{l}0.811^{* * *} \\
(0.166)\end{array}$ & & & & & \\
\hline Altruism & & $\begin{array}{c}0.061 \\
(0.065)\end{array}$ & & & & \\
\hline Strong egalitarian & & & $\begin{array}{c}0.057 \\
(0.114)\end{array}$ & & & \\
\hline Discount rate & & & & $\begin{array}{c}-0.006^{* * *} \\
(0.002)\end{array}$ & & \\
\hline Personal to general trust ratio & & & & & $\begin{array}{c}0.707^{* * *} \\
(0.164)\end{array}$ & \\
\hline Civic engagement & & & & & & $\begin{array}{c}0.367^{* * *} \\
(0.092)\end{array}$ \\
\hline Individual controls & $\mathrm{x}$ & $\mathrm{x}$ & $\mathrm{x}$ & $\mathrm{x}$ & $\mathrm{x}$ & $\mathrm{x}$ \\
\hline Village fixed-effects & $\mathrm{x}$ & $\mathrm{x}$ & $\mathrm{x}$ & $\mathrm{x}$ & $\mathrm{x}$ & $\mathrm{x}$ \\
\hline Observations & 517 & 547 & 554 & 414 & 554 & 541 \\
\hline (Pseudo) R-squared & 0.272 & 0.224 & 0.219 & 0.267 & 0.255 & 0.267 \\
\hline Number of clusters & 21 & 21 & 21 & 21 & 21 & 21 \\
\hline
\end{tabular}

Notes. Individual controls: ingroup treatment, age, gender, education, religion, marital status, ethnicity, household per capita expenditure, household size, number of years spent in the village. Observations clustered at the village level. 
Table A4. Treatment effects

\begin{tabular}{|c|c|c|c|c|c|c|c|c|}
\hline & & & & Depende & variable: & & & \\
\hline & $\begin{array}{l}\text { Donation } \\
\text { (oprobit) }\end{array}$ & $\begin{array}{l}\text { Donation } \\
\text { (oprobit) }\end{array}$ & $\begin{array}{l}\text { Donation } \\
\text { (oprobit) }\end{array}$ & $\begin{array}{l}\text { Donation } \\
\text { (oprobit) }\end{array}$ & $\begin{array}{l}\text { Donation } \\
\text { (oprobit) }\end{array}$ & $\begin{array}{l}\text { Donation } \\
\text { (oprobit) }\end{array}$ & $\begin{array}{l}\text { Donation } \\
\text { (oprobit) }\end{array}$ & $\begin{array}{l}\text { Donation } \\
\text { (oprobit) }\end{array}$ \\
\hline & (1) & (2) & (3) & (4) & (5) & (6) & (7) & (8) \\
\hline $\begin{array}{l}\text { Ingroup* Exposure-dependence index } \\
\text { (experienced degradation) }\end{array}$ & $\begin{array}{c}0.001 \\
(0.233)\end{array}$ & & & & & & & \\
\hline Ingroup*Altruism & & $\begin{array}{c}0.140 \\
(0.117)\end{array}$ & & & & & & \\
\hline Ingroup*Strong elgalitarian & & & $\begin{array}{l}-0.131 \\
(0.341)\end{array}$ & & & & & \\
\hline Ingroup*Discount rate & & & & $\begin{array}{l}-0.000 \\
(0.003)\end{array}$ & & & & \\
\hline $\begin{array}{l}\text { Ingroup*Personal to general trust } \\
\text { ratio }\end{array}$ & & & & & $\begin{array}{l}-0.179 \\
(0.204)\end{array}$ & & & \\
\hline Ingroup*Civic engagement & & & & & & $\begin{array}{c}-0.072 \\
(0.138)\end{array}$ & & \\
\hline Ingroup*Years living in village & & & & & & & $\begin{array}{l}-0.000 \\
(0.006)\end{array}$ & \\
\hline Ingroup*War exposure & & & & & & & & $\begin{array}{c}0.145 \\
(0.092)\end{array}$ \\
\hline
\end{tabular}




\begin{tabular}{|c|c|c|c|c|c|c|c|c|}
\hline Ingroup & $\begin{array}{c}-0.165 \\
(0.244)\end{array}$ & $\begin{array}{c}-0.351^{*} \\
(0.213)\end{array}$ & $\begin{array}{c}-0.123 \\
(0.193)\end{array}$ & $\begin{array}{c}-0.161 \\
(0.239)\end{array}$ & $\begin{array}{c}0.060 \\
(0.265)\end{array}$ & $\begin{array}{c}0.126 \\
(0.573)\end{array}$ & $\begin{array}{c}-0.153 \\
(0.238)\end{array}$ & $\begin{array}{c}-0.936^{*} \\
(0.507)\end{array}$ \\
\hline Environmental degradation & $\begin{array}{l}0.411^{* *} \\
(0.192)\end{array}$ & $\begin{array}{l}0.407^{* *} \\
(0.159)\end{array}$ & $\begin{array}{l}0.410^{* * *} \\
\quad(0.158)\end{array}$ & $\begin{array}{r}0.411^{* * *} \\
(0.158)\end{array}$ & $\begin{array}{r}0.403^{* * *} \\
(0.155)\end{array}$ & $\begin{array}{l}0.412^{* * *} \\
(0.160)\end{array}$ & $\begin{array}{r}0.410^{* * *} \\
(0.159)\end{array}$ & $\begin{array}{r}0.412^{* * *} \\
(0.156)\end{array}$ \\
\hline Altruism & $\begin{array}{l}0.219^{* * *} \\
(0.056)\end{array}$ & $\begin{array}{l}0.141 \\
\quad(0.096)\end{array}$ & $\begin{array}{r}0.218^{* * *} \\
(0.058)\end{array}$ & $\begin{array}{l}0.219^{* * *} \\
(0.058)\end{array}$ & $\begin{array}{l}0.222^{* * *} \\
(0.057)\end{array}$ & $\begin{array}{l}0.218^{* * *} \\
(0.056)\end{array}$ & $\begin{array}{r}0.220^{* * *} \\
(0.055)\end{array}$ & $\begin{array}{r}0.221^{* * *} \\
(0.058)\end{array}$ \\
\hline Strong egalitarian & $\begin{array}{r}0.400^{* * *} \\
(0.153)\end{array}$ & $\begin{array}{l}0.417^{* * *} \\
(0.159)\end{array}$ & $\begin{array}{c}0.468^{*} \\
(0.249)\end{array}$ & $\begin{array}{r}0.400^{* *} \\
(0.156)\end{array}$ & $\begin{array}{r}0.399 * * * \\
(0.154)\end{array}$ & $\begin{array}{l}0.411^{* * *} \\
(0.158)\end{array}$ & $\begin{array}{r}0.401^{* * *} \\
(0.154)\end{array}$ & $\begin{array}{c}0.378^{* *} \\
(0.149)\end{array}$ \\
\hline Discount rate & $\begin{array}{c}0.000 \\
(0.001)\end{array}$ & $\begin{array}{c}0.000 \\
(0.001)\end{array}$ & $\begin{array}{c}0.000 \\
(0.001)\end{array}$ & $\begin{array}{c}0.000 \\
(0.002)\end{array}$ & $\begin{array}{c}0.000 \\
(0.001)\end{array}$ & $\begin{array}{c}0.000 \\
(0.001)\end{array}$ & $\begin{array}{c}0.000 \\
(0.001)\end{array}$ & $\begin{array}{c}0.000 \\
(0.001)\end{array}$ \\
\hline Personal to general trust ratio & $\begin{array}{c}-0.094 \\
(0.143)\end{array}$ & $\begin{array}{c}-0.094 \\
(0.142)\end{array}$ & $\begin{array}{c}-0.095 \\
(0.144)\end{array}$ & $\begin{array}{c}-0.094 \\
(0.140)\end{array}$ & $\begin{array}{c}0.002 \\
(0.158)\end{array}$ & $\begin{array}{c}-0.101 \\
(0.142)\end{array}$ & $\begin{array}{c}-0.094 \\
(0.143)\end{array}$ & $\begin{array}{c}-0.084 \\
(0.143)\end{array}$ \\
\hline Civic engagement & $\begin{array}{c}0.013 \\
(0.063) \\
\end{array}$ & $\begin{array}{c}0.012 \\
(0.061) \\
\end{array}$ & $\begin{array}{c}0.017 \\
(0.064) \\
\end{array}$ & $\begin{array}{c}0.013 \\
(0.063) \\
\end{array}$ & $\begin{array}{c}0.009 \\
(0.065) \\
\end{array}$ & $\begin{array}{c}0.049 \\
(0.086) \\
\end{array}$ & $\begin{array}{c}0.013 \\
(0.062) \\
\end{array}$ & $\begin{array}{c}0.009 \\
(0.062) \\
\end{array}$ \\
\hline Individual controls & $\mathrm{x}$ & $\mathrm{x}$ & $\mathrm{x}$ & $\mathrm{x}$ & $\mathrm{x}$ & $\mathrm{x}$ & $\mathrm{x}$ & $\mathrm{x}$ \\
\hline Village fixed-effects & $\mathrm{x}$ & $\mathrm{x}$ & $\mathrm{x}$ & $\mathrm{x}$ & $\mathrm{x}$ & $\mathrm{x}$ & $\mathrm{x}$ & $\mathrm{x}$ \\
\hline Observations & 370 & 370 & 370 & 370 & 370 & 370 & 370 & 370 \\
\hline (Pseudo) R-squared & 0.088 & 0.090 & 0.088 & 0.088 & 0.088 & 0.088 & 0.088 & 0.091 \\
\hline Number of clusters & 21 & 21 & 21 & 21 & 21 & 21 & 21 & 21 \\
\hline
\end{tabular}


Appendix B. Variable description

\begin{tabular}{|c|c|c|}
\hline Variable & Type & Descritpion \\
\hline Donation & $\begin{array}{l}\text { Ordered } \\
\text { Response }\end{array}$ & $\begin{array}{l}\text { Amount donated to CSSL: } 0,300,800 \text {, or } \\
\text { 1000 Leones }\end{array}$ \\
\hline WaterMaintenance & Dummy & $\begin{array}{l}\text { Equal to } 1 \text { if answer to the following } \\
\text { question = Yes: } \\
\text { Did you contribute last time this water } \\
\text { source (the one your HH uses) needed } \\
\text { maintenance? }\end{array}$ \\
\hline Townclean & Dummy & $\begin{array}{l}\text { Equal to } 1 \text { if answer to the following } \\
\text { question = Yes: } \\
\text { Have you participated in road brushing } \\
\text { or town cleaning in the past year? }\end{array}$ \\
\hline $\begin{array}{l}\text { Strong preferences for } \\
\text { conservation }\end{array}$ & Dummy & $\begin{array}{l}\text { Equal to } 1 \text { if: } \\
-\quad \text { Amount donated to CSSL>average } \\
\text { amount donated to CSSL by all } \\
\text { participants } \\
-\quad \text { WaterMaintenance }=1 \\
-\quad \text { Townclean }=1 \\
\end{array}$ \\
\hline $\begin{array}{l}\text { Firewood time } \\
\text { increased }\end{array}$ & Dummy & $\begin{array}{l}\text { Equal to } 1 \text { if answer to the following } \\
\text { question = Increased: } \\
\text { Has the time it takes to collect firewood } \\
\text { increased/decreased over the last } 2 \\
\text { years? }\end{array}$ \\
\hline Environmental shocks & Dummy & $\begin{array}{l}\text { Equal to } 1 \text { if answer to the following } \\
\text { question = Yes: } \\
\text { In the past } 3 \text { years, have you lost any } \\
\text { income due to flooding, draught, water } \\
\text { contamination, pollution or other } \\
\text { environmental shocks? }\end{array}$ \\
\hline $\begin{array}{l}\text { Environmental } \\
\text { Degradation }\end{array}$ & Dummy & $\begin{array}{l}\text { Equal to } 1 \text { if Firewood time increased = } \\
1 \text { or Environmental shocks = } 1\end{array}$ \\
\hline Altruism & $\begin{array}{l}\text { Ordered } \\
\text { Response }\end{array}$ & $\begin{array}{l}\text { Number of tokens sent in Dictator game: } \\
0,1,2,3 \text { or } 4\end{array}$ \\
\hline Strong egalitarian & Dummy & $\begin{array}{l}\text { Equal to } 1 \text { if tokens sent in Dictator } \\
\text { game }=2 \text { AND tokens sent in Ultimatum } \\
\text { game }=2\end{array}$ \\
\hline Discount rate & $\begin{array}{l}\text { Ordered } \\
\text { Response }\end{array}$ & $\begin{array}{l}\text { Equal to } 0,20,50,100,150 \text { or } 200 \\
\text { depending on answers to the following } \\
\text { series of questions: } \\
\text { Imagine you have won the lottery. You } \\
\text { can choose between being paid today or } \\
\text { a different amount in a month. Which } \\
\text { option do you prefer? Imagine that you } \\
\text { are certain that the money will come for } \\
\text { sure in one month. } \\
100,000 \text { Le today or 100,000 in one } \\
\text { month }\end{array}$ \\
\hline
\end{tabular}


100,000 Le today or 150,000 in one month

100,000 Le today or 200,000 in one month

100,000 Le today or 250,000 in one month

100,000 Le today or 300,000 in one month 